7. Reprod. Fert. (1969) 20, 69-76

\title{
DELAYED FERTILIZATION AND CHROMOSOMAL ANOMALIES IN MOUSE EMBRYOS
}

\author{
ANNE D. VIGKERS \\ Physiological Laboratory, University of Cambridge \\ (Received 13th August 1968, revised 30th October 1968)
}

\begin{abstract}
Summary. Chromosomes were studied in mouse embryos and foetuses recovered after superovulation. The spontaneous incidence of chromosomal anomalies was $2.6 \%$; a delay of 7 to $13 \mathrm{hr}$ before fertilization produced $3.9 \%$ anomalies. The most striking feature was a nine-fold increase in the incidence of triploidy after delayed fertilization. The chromosomal anomalies included isochromosomes and minute chromosomes. Some anomalous individuals survive implantation and the fate of such foetuses is discussed.
\end{abstract}

\section{INTRODUCTION}

Three main events lead to chromosomal anomalies at the time of fertilization: meiotic errors, fertilization errors and cleavage errors. In general terms: meiotic errors give rise to karyotypes with numerical or structural changes, fertilization errors produce karyotypes with numerical changes, and cleavage errors produce mosaic embryos (although complete suppression of the first cleavage division produces a tetraploid embryo).

Fertilization of ageing eggs (delayed fertilization) leads to an increased incidence of chromosomal anomalies in amphibians, rats, rabbits and pigs. Witschi \& Laguens (1963) delayed fertilization of frog and toad eggs for 3 to 5 days and found that embryos recovered after hatching showed an increased incidence of meiotic, fertilization and cleavage errors. Austin \& Braden (1953) found that delaying fertilization for some hours after ovulation increased the incidence of polyspermy from $1.5 \%$ to $9.2 \%$ in rats, and from $0.5 \%$ to $13 \%$ in rabbits. Shaver \& Carr (1967) made similar observations on rabbits. Austin (1967), in a later study on rabbits, found that delayed fertilization resulted in a three-fold increase in the incidence of hypodiploid embryos. These anomalies were produced by disintegration of the second meiotic spindle in ageing eggs. After delayed fertilization in the sow, Thibault (1959) found $20 \%$ digyny plus $11 \%$ diandry, Hancock (1959) found $40 \%$ triploid embryos, and BomselHelmreich (1965) found $6 \%$ triploid embryos.

However, Gates \& Beatty (1954) and Braden \& Austin (1954) found that delayed fertilization in the mouse did not increase the incidence of triploidy. Since an improved method for preparing chromosomes from mouse embryos has been developed recently (Tarkowski, 1966), it seemed worthwhile to reinvestigate the effect of delayed fertilization on mouse embryos in spite of these negative reports. The fate of chromosomally abnormal individuals is of interest, and so post-implantation material was also studied. 


\section{MATERIAL AND METHODS}

These results are derived from the same material which provided the sex-ratio data reported in a separate communication (Vickers, 1969). PDE mice, an albino strain, were induced to superovulate; the control group was allowed to mate at the time of ovulation but the delayed fertilization groups were not allowed to mate except between 5 and $11 \mathrm{hr}$ after ovulation.

Embryos were recovered 3 to 4 days after ovulation and chromosome preparations were made as previously described (Vickers, 1967a). Most chromosome counts were precise, but some were estimated as diploid \pm 2 chromosomes.

A few chromosome preparations were made $9 \frac{1}{2}$ to $11 \frac{1}{2}$ days after ovulation by a squash technique (Piko \& Bomsel-Helmreich, 1960) but the results were unsatisfactory and so most of the preparations at this time were made from the whole foetus or foetal liver by the method of Ford \& Woollam (1963). The technique was modified for the younger foetuses as follows: the foetus was left intact until after fixation and then broken up by gentle pipetting in $45 \%$ acetic acid before air-drying. The modification was always successful with $9 \frac{1}{2}$ - and $10 \frac{1}{2}$-day-old foetuses and could even be applied to smaller quantities of tissue, for example the tail of a 9 $\frac{1}{2}$-day-old foetus. The modification was, however, unsuitable for use on $11 \frac{1}{2}$-day-old foetuses because they did not break up readily after fixation. Amniotic preparations were made from most of the foetuses recovered and the sex chromatin patterns were studied as previously described (Vickers, 1967b).

Two microscope slides were prepared from each foetus and, if possible, at least ten well-spread metaphases were studied from each slide. Metaphases were selected at a magnification of $\times 100$ and studied in detail at a magnification of $\times 900$. Karyotyping was not attempted. The foetus was recorded as diploid when most of the metaphases contained 40 chromosomes. Occasional cells with 39 or fewer chromosomes were presumed to be artefacts. Where fewer than twenty metaphases were suitable for analysis, the foetus was recorded as '? diploid' because of the possibility of undetected mosaicism.

\section{RESULTS}

\section{Control group $3 \frac{1}{2}$ days after ovulation}

The results of the chromosomal analysis of 309 embryos obtained from thirty-two pregnant mice are presented in Tables 1 and 2. These results include those presented previously (Vickers, 1967a).

The single haploid blastocyst appeared degenerate on recovery and six of the thirty-two cells had pycnotic nuclei.

There were two trisomic embryos; one of them had a double blastocoele, and it is tempting to speculate on the association of these two events in one embryo. In the present series of investigations, trisomy occurred in three out of 1000 embryos and a double blastocoele in two out of 309 embryos so that the probability of finding these two independent events in the same embryo is 0.000019 . The association was not invariable: one of the embryos with a double blastocoele was diploid, while the other trisomic embryo formed a normal blastocyst. 
TABLE 1

THE CHROMOSOME COMPLEMENTS OF EIGHT SPONTANEOUS HETEROPLOID EMBRYOS RECOVERED $3 \frac{1}{2}$ DAYS AFTER OVULATION

\begin{tabular}{|c|c|c|c|c|c|c|c|c|c|c|c|c|}
\hline \multirow{2}{*}{ Anomaly } & \multirow{2}{*}{$\begin{array}{l}\text { Total cells } \\
\text { in embryo }\end{array}$} & \multicolumn{10}{|c|}{ No. of cells assigned to chromasome class } & \multirow{2}{*}{ Sex } \\
\hline & & 20 & 34 & $37 \$$ & 39 & $\begin{array}{l}\text { No. o } \\
40^{\circ}\end{array}$ & chromo $40^{\dagger}$ & $\begin{array}{c}\text { osomes } \\
40^{*}\end{array}$ & 41 & 60 & $60 \pm 2$ & \\
\hline $\begin{array}{l}\ln n_{+}^{*} \\
3 n \\
2 n+1 \\
2 n+1 \\
2 n^{*} \ddagger \\
\text { Mosaic } \\
2 n \dagger \\
2 n / 2 n^{\dagger}\end{array}$ & $\begin{array}{l}32 \\
54 \\
55 \\
84 \\
56 \\
37 \\
34 \\
58\end{array}$ & 3 & 1 & 1 & 1 & 6 & $\begin{array}{l}1 \\
2\end{array}$ & 3 & $\begin{array}{l}1 \\
1\end{array}$ & 1 & 3 & $\begin{array}{l}? \\
? \\
\text { XY } \\
\mathrm{XY} \\
\mathrm{XY} \\
? \\
\mathrm{XY} \\
\mathrm{XX}\end{array}$ \\
\hline
\end{tabular}

* Complement includes a minute chromosome.

$\dagger$ Complement includes an isochromosome.

† Siblings.

\$ Complement includes two minute chromosomes.

TABLE 2

THE DISTRIBUTION OF CONTROL MOUSE EMBRYOS $3 \frac{1}{2}$ DAYS AFTER OVULATION

\begin{tabular}{l|c|c}
\hline Type & No. embryos & $\%$ embryos typed \\
\cline { 2 - 3 } & 301 & $97 \cdot 41$ \\
Presumed normal: & 226 & $73 \cdot 13$ \\
$2 \mathrm{n}$ & 75 & $24 \cdot 28$ \\
$2 \mathrm{n} \pm 2$ & 8 & $2 \cdot 59$ \\
Heteroploid: & 1 & $0 \cdot 32$ \\
$\ln$ & 1 & $0 \cdot 32$ \\
$3 \mathrm{n}$ & 2 & $0 \cdot 65$ \\
$2 \mathrm{n}+1$ & 2 & $0 \cdot 32$ \\
$2 \mathrm{n}^{*}$ & 1 & $0 \cdot 65$ \\
Mosaic & 0.32 \\
$2 \mathrm{n} \dagger$ & \multicolumn{2}{c}{}
\end{tabular}

Minute chromosomes were found in two embryos (PI. 1, Figs. 1 and 2); one of these embryos was a complex hypodiploid mosaic. The minute chromosomes may have been produced by a deletion or a translocation.

An isochromosome was present in two embryos (Pl. 1, Figs. 3 and 4); one of these embryos was a mosaic and it can be deduced that the isochromosome arose at the second or third cleavage division (probably from a misdivision of the centromere).

Most of the heteroploid embryos were of normal morphological appearance both before and after fixation and might well have continued to develop; the exceptions were the haploid embryo and one of the trisomic embryos.

\section{Delayed group 3 to 4 days after ovulation}

Twenty-nine pregnant mice provided 207 embryos suitable for chromosomal analysis (Tables 3 and 4 ). 
TABLE 3

THE GHROMOSOME COMPLEMENTS OF EIGHT HETEROPLOI EMBRYOS RECOVERED 3 TO 4 DAYS AFTER DELAYED FERTILIZATION

\begin{tabular}{|c|c|c|c|c|c|c|c|}
\hline \multirow{2}{*}{ Anomaly } & \multirow{2}{*}{$\begin{array}{l}\text { Total cells } \\
\text { in embryo }\end{array}$} & \multicolumn{5}{|c|}{ No. of cells assigned to chromosome class } & \multirow{2}{*}{$\operatorname{Sex}$} \\
\hline & & 39 & $\begin{array}{ll} & \text { No } \\
50 \text { to } & 60\end{array}$ & $\begin{array}{l}\text { f chro } \\
60\end{array}$ & $\begin{array}{l}\text { mes } \\
60 \pm 2\end{array}$ & 80 & \\
\hline $\begin{array}{l}3 n \\
3 n \\
3 n \\
3 n \\
3 n^{*} \\
3 n \\
4 n \\
2 n-1^{*}\end{array}$ & $\begin{array}{l}35 \\
58 \\
18 \\
18 \\
59 \\
93 \\
27 \\
55\end{array}$ & 3 & $\begin{array}{l}2 \\
1\end{array}$ & $\begin{array}{l}1 \\
2 \\
1 \\
2\end{array}$ & $\begin{array}{l}1 \\
7 \\
2 \\
\\
1\end{array}$ & 1 & $\begin{array}{l}\stackrel{?}{\mathrm{XXX}} \\
\stackrel{?}{?} \\
\stackrel{\mathrm{XXX}}{\mathrm{e}} \\
\stackrel{?}{?} \\
\stackrel{\mathrm{XX}}{\mathrm{X}} \text { or } \mathrm{XO}\end{array}$ \\
\hline
\end{tabular}

* Siblings.

TABLE 4

THE DISTRIBUTION OF MOUSE EMBRYOS RECOVERED

3 TO 4 DAYS AFTER DELAYED FERTILIZATION

\begin{tabular}{c|c|c}
\hline Type & No. embryos & \% embryos typed \\
\cline { 1 - 2 } Presumed normal: & 199 & $96 \cdot 14$ \\
2n & 120 & 57.97 \\
$2 \mathrm{n} \pm 2$ & 79 & $38 \cdot 16$ \\
Heteroploid: & 8 & $3 \cdot 86$ \\
3n & 6 & $2 \cdot 90$ \\
$4 \mathrm{n}$ & 1 & $0 \cdot 48$ \\
$2 \mathrm{n}-1$ & 1 & $0 \cdot 48$ \\
\hline
\end{tabular}

TABLE 5

THE CHROMOSOME COMPLEMENTS OF FIVE HETEROPLOID FOETUSES RECOVERED $9 \frac{1}{2}$ TO $11 \frac{1}{2}$ DAYS AFTER DELAYED FERTILIZATION

\begin{tabular}{|c|c|c|c|c|c|c|c|}
\hline \multirow{2}{*}{ Anomaly } & \multicolumn{6}{|c|}{$\begin{array}{c}\text { No. of cells assigned to chromosome } \\
\text { class }\end{array}$} & \multirow{2}{*}{ Sex } \\
\hline & 39 & 40 & 0. of $\mathrm{c}$ & $\begin{array}{l}\text { omosom } \\
40^{*}\end{array}$ & 50 to 60 & 60 & \\
\hline $\begin{array}{l}3 n \\
2 n-1 \\
2 n / 2 n(\min )^{*} \dagger \\
2 n / 2 n+1 / 2 n-1 \dagger \\
2 n / 2 n+1 / 2 n-1\end{array}$ & $\begin{array}{r}16 \\
6 \\
6\end{array}$ & $\begin{array}{l}48 \\
39 \\
46\end{array}$ & $\begin{array}{l}4 \\
3\end{array}$ & 2 & 4 & 5 & $\begin{array}{l}\text { XXX } \\
\text { XO } \\
\text { XY } \\
\text { XY } \\
\text { XX }\end{array}$ \\
\hline
\end{tabular}

* Complement includes a minute chromosome.

† Siblings.

The six triploid embryos and the one monosomic embryo all appeared morphologically normal before and after fixation. One tetraploid embryo, which appeared to be normal before fixation, proved to have some abnormally large nuclei and some pycnotic nuclei and was probably degenerating. 


\section{PLATE 1}

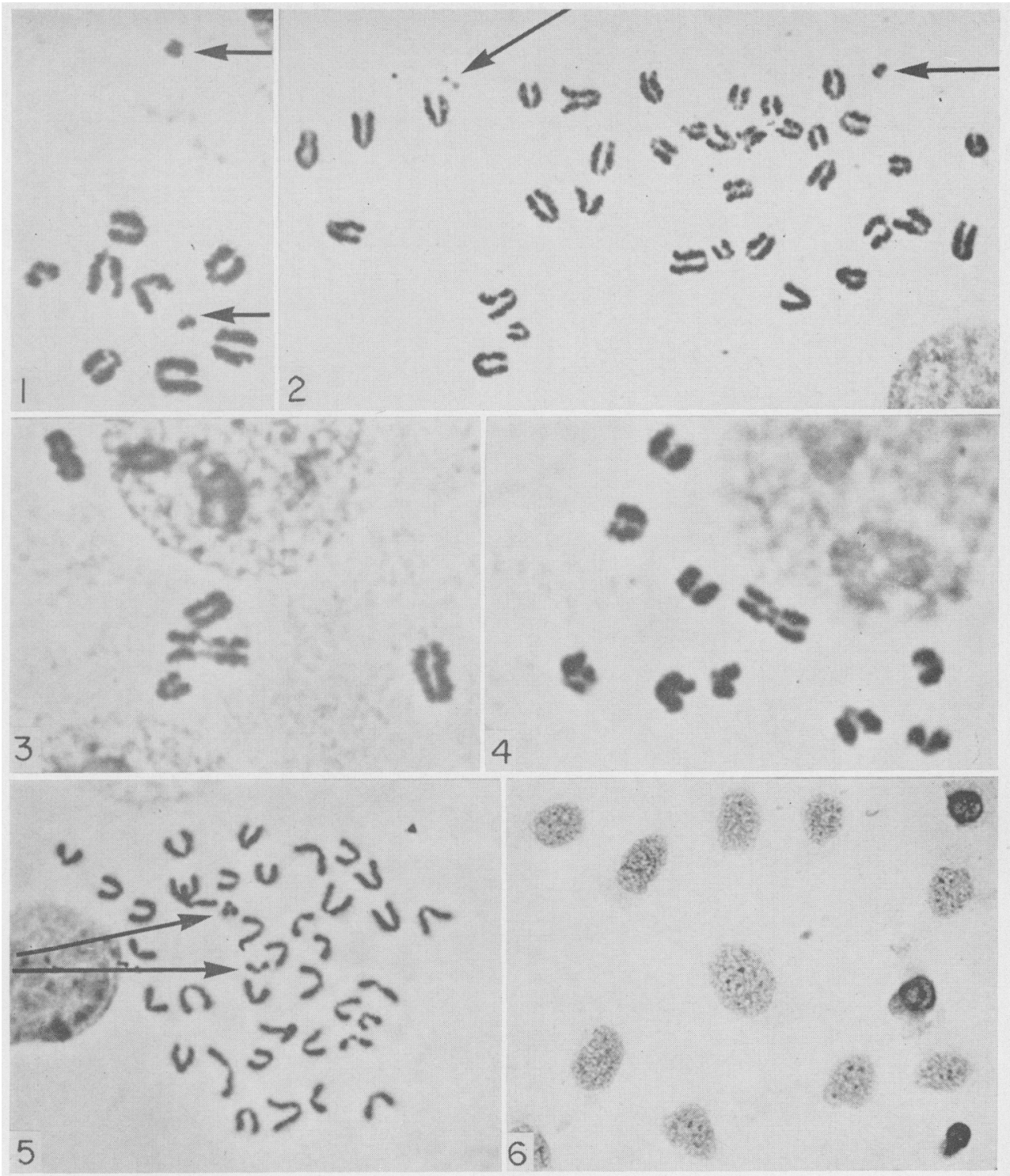

Fig. 1. Minute chromosomes (arrowed) in two adjacent metaphases from a control embryo: $2 \mathrm{n}(\mathrm{min}) . \times 2120$.

Fig. 2. Two minute chromosomes (arrowed) in one metaphase from a control embryo: mosaic. $\times 1350$.

FIG. 3. Isochromosome in a metaphase from a control embryo. $\times 2120$.

Fig. 4. Isochromosome in a different metaphase from the same embryo. $\times 2120$.

FIG. 5. XO foetus recovered $10 \frac{1}{2}$ days after delayed fertilization: metaphase containing 39 chromosomes with two small autosomes (arrowed) but no $Y$ chromosome. $\times 1350$. Fig. 6. No sex chromatin in the amnion from the XO foetus. $\times 540$.

(Facing p. 72) 
TABLE 6

THE DISTRIBUTION OF MOUSE FOETUSES RECOVERED $9 \frac{1}{2}$ TO $11 \frac{1}{2}$ DAYS AFTER DELAYED FERTILIZATION

\begin{tabular}{c|c|c}
\hline Type & No. foetuses & \% foetuses typed \\
\cline { 2 - 3 } Presumed normal: & 90 & $94 \cdot 74$ \\
2n & 60 & $63 \cdot 17$ \\
2n (?) & 30 & $31 \cdot 58$ \\
Heteroploid: & 5 & $5 \cdot 26$ \\
3n & 1 & $1 \cdot 05$ \\
2n-1 & 1 & $1 \cdot 05$ \\
Mosaic & 3 & $3 \cdot 16$ \\
\hline
\end{tabular}

\section{Delayed group $9 \frac{1}{2}$ to $11 \frac{1}{2}$ days after ovulation}

This age group was chosen with a view to determining the fate of triploid embryos. No control group was studied since the results $3 \frac{1}{2}$ days after ovulation had shown that triploidy was very rare in control animals. Eleven pregnant mice provided ninety-five foetuses suitable for chromosomal analysis (Tables 5 and 6).

The triploid foetus was structurally normal but smaller and paler than its ten diploid siblings, no heart beat could be detected and it seems likely that this foetus was dying. The sex chromatin constitution was not identified.

No siblings were available for developmental comparison with the single monosomic foetus. Each metaphase studied from this foetus showed 39 chromosomes including two very small autosomes but no Y chromosome (Pl. 1, Fig. 5). Independent examination of the amnion showed a male pattern of nuclear chromatin. Eight per cent of ectodermal cells contained sex chromatin-like bodies (Pl. 1, Fig. 6). These findings suggest that the foetus had an XO sex chromosome constitution.

There were three mosaic foetuses, all of which appeared to be developing normally. Two of the mosaic foetuses probably arose by unequal separation of the chromosomes at one of the early cleavage divisions. The minute chromosome in the other mosaic foetus was probably the result of a deletion or a translocation in one cell during development.

TABLE 7

THE EFFECT OF DELAYED FERTILIZATION AND IMPLANTATION ON VARIOUS TYPES OF CHROMOSOMAL ANOMALY

\begin{tabular}{l|c|c|c}
\hline \multirow{2}{*}{ Origin of anomaly } & \multicolumn{3}{|c}{ Anomalous young, expressed as \% young typed } \\
\cline { 2 - 4 } & $\begin{array}{c}3 \frac{1}{2} \text { day } \\
\text { Control }\end{array}$ & $\begin{array}{c}3 \text { to } 4 \text { day } \\
\text { Delay }\end{array}$ & $\begin{array}{c}9 \frac{1}{2} \text { to } 11 \frac{1}{2} \text { day } \\
\text { Delay }\end{array}$ \\
\hline Fertilization & 0.65 & 2.90 & 1.05 \\
Meiosis & 1.28 & 0.48 & 1.05 \\
Cleavage & 0.32 & 0.48 & 3.16 \\
Meiosis +cleavage & 0.32 & & \\
Total & 2.57 & 3.86 & 5.26 \\
\hline
\end{tabular}


The chromosomal anomalies found were classified according to the type of origin (Table 7); where there are theoretical alternatives, the most likely origin has been given. The $\mathrm{XO}$ foetus has been classed as a meiotic error although Russell (1961) suggests that XO mice arise by loss of the paternal sex chromosome from the pronucleus.

\section{DISCUSSION}

The abnormalities which can be detected are limited because all the chromosomes of the mouse are telocentric or acrocentric and very few can be recognized with certainty. Structural changes in individual chromosomes are unlikely to be detected unless the product is larger or smaller than all the other chromosomes present, but numerical changes in the karyotype will be detected without difficulty.

Most of the chromosomal anomalies reported here are paralleled in work on other species. Boué \& Boué (1966) found human spontaneous abortuses with mosaics of $2 n / 2 n+1 / 2 n-1$ and of $2 n / 2 n+1+$ minute. There are, however, no previous reports of an isochromosome occurring in an embryo. Isochromosomes of the sex chromosomes have been found in adult man (Moore, 1966; Jacobs \& Ross, 1966), but there are no previous reports of isochromosomes in any other mammalian species. It is not clear whether the PDE mouse embryos with an isochromosome would have survived.

Delayed fertilization can be seen to increase the incidence of fertilization errors. The nine-fold increase in the incidence of triploidy is statistically significant $\left(\chi^{2}=6 \cdot 14 ; P<0.02\right)$. This shows that ageing of the PDE mouse egg affects either the block to polyspermy or the formation of the second polar body. The latter appears more likely because of the sex chromosome constitution of two of the triploid embryos (XXX), and also because Braden \& Austin (1954) found that mouse triploids, whether spontaneous or resulting from heat shock, were all the result of digyny. Delayed fertilization increases the incidence of triploidy as a result of diandry in the rat and rabbit (Austin \& Braden, 1953) and as a result of digyny and diandry in the pig (Thibault, 1959). As already stated, Gates \& Beatty (1954) and Braden \& Austin (1954) found no significant increase in the incidence of triploidy in mouse embryos following delayed fertilization. The discrepancy between their results and the present findings may have arisen because they used immature mice or because of differences in the strain of mouse used. The incidence of spontaneous triploidy is affected by the strain in both mice (Beatty, 1957) and rats (Piko, 1958); also the incidence of triploidy after delayed fertilization is affected by the strain in rats (Piko, 1958).

Delayed fertilization in other species has a much more striking effect on the incidence of chromosomal anomalies. The differences in response probably reflect differences in the mechanics of fertilization between various species and between various strains.

The proportion of cleavage errors appears from Table 7 to be increased in the older age group but this finding needs further confirmation. The table also shows that some chromosomally abnormal individuals survive implanta- 
tion. The mosaic foetuses might have continued to develop normally because of the high proportion of diploid cells present. The monosomic foetus would almost certainly have survived since $\mathrm{XO}$ is the commonest chromosomal anomaly in

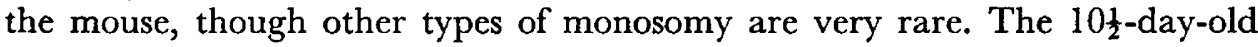
triploid found in these experiments was clearly abortive; Fishberg \& Beatty (1951) found seven (tone?) triploid mouse foetuses which were normal in appearance but smaller than their diploid siblings after $9 \frac{1}{2}$ days of gestation. Edwards (1958) found no aneuploid young born after a colchicine treatment which induced $11 \%$ of triploid embryos. Triploid foetuses are almost invariably lost during the first half of gestation in rats (Piko \& Bomsel-Helmreich, 1960), pigs and rabbits (Bomsel-Helmreich, 1965) and man (Edwards, Yuncken, Rushton, Richards \& Mittwoch, 1967). It appears that the same is true of mice.

\section{ACKNOWLEDGMENTS}

I should like to thank Dr R. G. Edwards, Dr T. Vickers and Mr R. Gardner for their advice and Miss V. Hunn for technical assistance. I am very grateful to Dr Tarkowski for allowing me to make use of his method. This work was supported by the Medical Research Gouncil and the Ford Foundation.

\section{REFERENCES}

Austin, C. R. (1967) Chromosome deterioration in ageing eggs of the rabbit. Nature, Lond. 213, 1018. Austin, C. R. \& Braden, A.W. H. (1953) Polyspermy in mammals. Nature, Lond. 172, 82.

Beatty, R. A. (1957) Parthenogenesis and polyploidy in mammalian development. Cambridge University Press, London.

Bomsel-Helmreich, O. (1965)Heteroploidy and embryonic death. In: Pre-implantation Stages of Pregnancy, Ciba Foundation Symposium, p. 246. Eds. G. E. W. Wolstenholme and M. O'Connor. Churchill, London.

BouÉ, J. G. \& BouÉ, A. (1966) Chromosomal aberrations in spontaneous human abortions. C. r. hebd. Séanc. Acad. Sci., Paris, D, 263, 2054.

Braden, A. W. H. \& Austin, C. R. (1954) Fertilization of the mouse egg and the effect of delayed coitus and of hot-shock treatment. Aust. J. biol. Sci. 7, 552.

Edwards, J. H., Yuncken, C., Rushton, D. I., Richards, S. \& MitTwoch, U. (1967) Three cases of triploidy in man. Cytogenetics, 6, 81 .

EDwards, R. G. (1958) Colchicine induced heteroploidy in the mouse. 1. The induction of triploidy by treatment of the gametes. F. exp. Zool. 137, 317 .

Fishberg, M. \& Beatty, R. A. (1951) Spontaneous heteroploidy in mouse embryos up to mid-term. 7. exp. Zool. 118, 321 .

Ford, E. H. R. \& Woollam, D. H. M. (1963) A colchicine, hypotonic citrate, air drying sequence for foetal mammalian chromosomes. Stain Technol. 38, 271.

Gates, A. H. \& BEATTY, R. A. (1954) Independence of delayed fertilization and spontaneous triploidy in mouse embryos. Nature, Lond. 174, 356.

Hancock, J. L. (1959) Polyspermy of pig ova. Anim. Prod. 1, 103.

JACOBs, P. A. \& Ross, A. (1966) Structural abnormalities of the Y chromosome in man. Nature, Lond. $210,352$.

Moore, K. L. (1966) The sex chromatin, p. 331. Saunders, London.

Piko, L. (1958) Etude de la polyspermie chez le rat. C. r. Séanc. Soc. Biol. 152, 1356.

Piko, L. \& Bomsel-Helmreich, O. (1960) Triploid rat embryos and other chromosomal deviants after colchicine treatment and polyspermy. Nature, Lond. 186, 737.

Russelt, L. B. (1961) Genetics of mammalian sex chromosomes. Science, N.Y. 133, 1795.

Shaver, E. L. \& CARR, D. H. (1967) Chromosome abnormalities in rabbit blastocysts following delayed fertilization. 7. Reprod. Fert. 14, 415.

TARKowski, A. K. (1966) An air-drying method for chromosome preparations from mouse eggs. Cytogenetics, 5, 394. 
Thrbaulr, C. (1959) Analyse de la fécondation de l'cuf de la truie après accouplement ou insémination artificelle. In: Colloquium on Reproduction and Artificial Insemination of the Pig, p. 165. Institut National de la Recherche Agronomique, Paris.

Vickers, A. D. (1967a) A direct measurement of the sex-ratio in mouse blastocysts. F. Reprod. Fert. 13, 375.

Vickers, A. D. (1967b) Amniotic sex chromatin and foetal sexing in the mouse. J. Reprod. Fert. 14, 503.

Vickers, A. D. (1969) Delayed fertilization and the prenatal sex-ratio of the mouse. F. Reprod. Fert. 20, 63.

Witschi, E. \& Laguens, R. (1963) Chromosomal aberrations in embryos from overripe eggs. Devt Biol. 7, 605. 